ISSN. 2775-4324 (Online)

Journal of Physical Activity and Sports

Volume 2, Nomor 2, Agustus 2021, 139-143

Journal of Physical Activity and Sports

\title{
Persepsi Siswa Terhadap Pembelajaran Daring Mata Pelajaran Pendidikan Jasmani Olahraga dan Kesehatan
}

\author{
Helmi Yuhdana Haryanto ${ }^{1}$, Saifullah Arif ${ }^{2}$ \\ ${ }^{12}$ Universitas Semarang \\ helmiyuhdana.13@gmail.com ${ }^{1}$, arifsaifullah648@gmail.com ${ }^{2}$
}

\begin{abstract}
In this study, the background is the difference in perceptions of students of SMK Negeri 10 Semarang in learning the subjects of Physical Education, Sports and Health (PJOK). So that it can be seen that the purpose of this study is to determine the perceptions of students, with the hope that it can be used as a reference in providing learning methods in the next academic year. The number of samples used was 112 students using the simple random sampling technique. The conclusion from this study was that the perceptions of students of SMK Negeri 10 Semarang had a positive perception of learning PJOK subjects that could be categorized as good with an average percentage of $83.7 \%$. This can be used as a reference in providing future learning techniques to use the same method so that students can understand the material well and are motivated to follow PJOK subjects and students do not experience boredom in the process of teaching and learning activities.
\end{abstract}

Keywords : Perception, Motivation, PJOK and Students

\begin{abstract}
Abstrak
Dalam penelitian ini yang menjadi latar belakang adalah adanya mengenai perbedaan persepsi pada Murid SMK Negeri 10 Semarang dalam pembelajaran mata pelajaran Pendidikan Jasmanai Olahraga Dan Kesehatan (PJOK). Sehingga dapat diketahui tujuan dari penelitian ini untuk mengetahui persepsi murid, dengan harapan bisa dijadikan sebagai acuan dalam pemberian metode pembelajaran pada tahun ajaran berikutnya. Jumlah sample yang digunakan sebesar 112 murid dengan menggunakan Tehnik Simple Random Sampling. Kesimpulan dari penelitian ini didapatkan jika persepsi murid SMK Negeri 10 Semarang memiliki persepsi yang positif mengenai pembelajaran mata pelajaran PJOK bisa dikategorikan baik dengan prosentase rata-rata sebesar $83,7 \%$. Hal ini yang bisa dijadikan acuan dalam pemberian tehnik pembelajaran kedepan nya untuk menggunakan metode yang sama sehingga murid bisa memahami materi dengan baik dan termotivasi untuk mengikuit mata pelajaran PJOK dan murid tidak mengalami kejenuhan dalam proses kegiatan belajar mengajar.
\end{abstract}

Kata Kunci : Persepsi, Motivasi, PJOK, Siswa

\section{PENDAHULUAN}

Dalam dunia pendidikan mata pelajaran pendidikan jasmani olahraga dan kesehatan memiliki peran yang sangat besar, oleh sebab itu dari tingkat dasar sampai tingkat perguruaan tinggi mata pelajaran ini tidak pernah dihilangkan, Pendidikan ini mampu memberikan peluang terhadap siswa 
untuk terlibat langsung dalam aktivitas jasmani (Pahliwandari,2016). Dimana mata pelajaran ini merupakan suatu proses yang mampu menjadikan seseorang mampu mendapatkan pertumbuhan dan perkembangan secara jasmani. Menurut Rahayu (2013) pendidikan jasmani olahraga dan kesehatan merupakan bagian dari integral pada suatu pendidikan secara keseluruhan, merupakan suatu proses pendidikan melalui aktifitas fisik yang dipilih untuk meningkatkan serta mengembangkan kemampuan organik, neuromaskuler, interoeratif, sosial dan emosional.Tujuan dari pendidikan jasmani olahraga dan kesehatan merupakan suatu bagian integral dari seluruh pendidikan dan bertujuan aspek kebugaran kasmani, ketrampilan berfikir kritis, ketrampilan sosial, penalaran, stabilitas, emosional tindakan moral, aspek pola hidup sehat yang direncanakan secara sistematik dalam rangka mencapai tujuan, selain itu secara umum pendidikan olahraga dan kesehatan adalah merupakan suatu usaha untuk membuat bangsa sehat dan kuat (Mukhammad Fitron, 2020).

Dalam masa pendemi seperti saat ini dimana proses belajar mengajar tidak bisa dilakukan secara langsung dengan tatap muka. Sehingga dengan adanya keterbatasan mengenai media pembelajaran, sering terjadi perbedaan persepsi antara guru dengan murid. Dimana PJOK merupakan salah satu mata pelajaran yang menggabungkan teori dan praktek secara langsung. Persepsi yang diberikan oleh ssiswa terhadap mata pelajaran PJOK sangat bervariasi, ada yang berpendapat negatif dan juga ada yang berpendapat positif. Dimana pendapat negatif ditandai masih sering absen saat mata kuliah dimulai dan tidak aktif dalam kegiatan belajar mengajar, mengenai pendapat mahasiswa yang memiliki pendapat positif ditandai dengan mereka selalu aktif dalam kegiatan belajar mengajar dan selalu berperan dalam kegiatan praktek. Menurut pendapat Suhadi dan Nur Cahyo (2014) Persepsi merupakan suatu aspek kognitif yang sangat penting bagi manusia, yang memungkinkan nya untuk mengetahui dan memahami terhadap lingkugan sekitar. Sedangkan Modeiro (2018) menjelaskan mengenai persepsi merupakan suatu proses dimana individu mengatur dan menafsirkan inderawi mereka merasakan untuk memberi makna pada lingkungan mereka. Dimana dapat terbentuknya suatu persepsi dimulai dengan pengamatan yang melalui proses hubungan melihat, mendengar, ,menyentuh, merasakan, dan menerima informasi yang diterima nya menjadi gambaran (Whitney, D.2012). Dari sebuah pengamatan yang dilakukan mahasiswa terhadap Mata Kuliah Pendidikan Jasmani olahraga dan kesehatan (PJOK) nantinya akan menimbulkan suatu persepsi baik itu bersifat positif ataupun negatif tergantung sudut pandang dari mahasiswa tersebut Komarudin dan Mardianto (2020).

Suprihatini (2013) menjelaskan jika pembelajaran merupakan suatu usaha yang dilakukan tenaga pengajar untuk membantu siswa mendapatkan ilmu pengetahuan yang bertujuan dalam mempermudah mencapai tujuan. Dalam dunia pendidikan Mata pelajaran PJOK mampu memberikan kesempatan kepada mahasiswa untuk terlibat secara langsung mengenai pengalaman belajar melalui kegiatan secara fisik. Tetapi persepsi yang timbul dari pembelajaran pada murid SMK Negeri 10 Semarang dirasa kurang efektif hal ini dikarnakan mahasiswa kurang memperhatikan secara 
menyeluruh arti pentingnya pendidikan olahraga dan kesehatan. Untuk mengatasi kejenuhan mahasiswa dalam kegiatan belajar mengajar dilakukan harus secara efektif, menarik dan profesional. Dengan perencanaan pembelajaran baik secara teori ataupun praktek secara langsung diharapkan mampu menarik keingingnan mahasiswa untuk mendapatkan hasil yang sesuai harapan. Persepsi ini diterima ketika manusia menerima stimulus dari luar yang ditangkap oleh organ-organ bantuan nya, setelah itu diteruskan kedalam otak (Agastya,2015).

Pada Penelitian terdahulu yang dilakukan oleh Komarudin dan Mardianto (2020) yang berjudul "Persepsi Siswa Terhadap Pembelajaran Daring Mata Pelajaran Pendidikan Jasmani Olahraga Dan Kesehatan Pada Masa Pandemi Covid 19" berpendapat jika persepsi siswa terhadap mata pelajaran Pendidikan jasmani dan kesehatan dapat dikategorikan sedang. Irfan Rahman dan Irfan Abdul Ghani (2020) pada penelitian yang berjudul “ Persepsi Siswa Pada Pembelajaran Pendidikan Jasmani Olahraga Dan Kesehatan Tingkat SMA” berpendapat jika persepsi murid kurang baik terhadap pembelajaran pendidikan jasmani olah raga dan kesehatan. Berdasarkan adanya perbedaan pada penelitian terdahulu mengenai persepsi murid terhadap mata pelajaran PJOK, sehingga peneliti tertarik mengambil materi presepsi pada murid SMK Negeri 10 Semarang untuk dijadikan pedoman mengenai tehnik pembelajaran pada berikutnya.

\section{METODE}

Dalam penelitian ini menggunakan penelitian deskriptif kuantitatif dimana pengambilan data dengan menggunakan angket atau kuesioner. Penelitian ini bertujuan untuk mengetahui tingkat persepsi murid SMK Negeri 10 Semarang Pendidikan Jasmani Olahraga dan Kesehartan. Dalam penelitian ini sample yang digunakan sebesar 112 Murid SMK Negeri 10 Semarang. Simple Ramdom Sampling adalah tehnik yang digunakan dalan pengambilan sample. Mengenai instrumen yang digunakan dalam penelitian ini adalah kuesioner dengan sejumlah 30 butir pertanyaan dengan lima skor penliaian dari jawaban kuesioner tersebut. Untuk mengukur kuesioner tersebut menggunkana skala liker untuk mengukur sikap, motivasi, persepsi serta pendapat seseorang untuk mengetahui fenomena sosial yang ada (Sugiono 2018). Dari hasil distribusi Frekwensi kemudian dimasukan kedalam kategori seseuai kriteria. Berikut tabel distribusi katergori menurut Sugiono (2010) Sbb :

\section{Tabel 1. Penskoran}

\begin{tabular}{ccc} 
No & Skor Interval & Kategori \\
\hline 1 & $90 \%-100 \%$ & Sangat Baik \\
\hline 2 & $80 \%-89 \%$ & Baik \\
\hline 3 & $70 \%-79 \%$ & Cukup Baik \\
\hline 4 & $55 \%-59 \%$ & Kurang Baik \\
\hline 5 & $<55 \%$ & Sangat Tidak Baik \\
\hline
\end{tabular}




\section{HASIL DAN PEMBAHASAN}

Berdasarkan olah data secara deskriptif dari sample murid sebanyak 112 didapatkan nilai maksimal sebesar 1.680 dengan perhitungan sebagai berikut :

Tabel 2. Hasil Perhitungan

\begin{tabular}{llllll}
\hline No & \multicolumn{1}{c}{ Aspek } & $\begin{array}{c}\text { Total } \\
\text { Score }\end{array}$ & $\begin{array}{c}\text { Hasil } \\
\text { Score }\end{array}$ & $\%$ & Ket \\
\hline 1 & Proeses Belajar & 1.680 & 1390 & $83 \%$ & Baik \\
\hline 2 & Motivasi & 1.680 & 1415 & $84 \%$ & Baik \\
\hline 3 & Kepribadian & 1.680 & 1355 & $81 \%$ & Baik \\
\hline 4 & Intensitas & 1.680 & 1450 & $86 \%$ & Baik \\
\hline 5 & Size & 1.680 & 1464 & $87 \%$ & Baik \\
\hline 6 & Keberlawanan & 1.680 & 1393 & $83 \%$ & Baik \\
\hline 7 & Pengulangan & 1.680 & 1399 & $83 \%$ & Baik \\
\hline 8 & Gerakan & 1.680 & 1426 & $85 \%$ & Baik \\
\hline 9 & Hal baru & 1.680 & 1384 & $82 \%$ & Baik \\
\hline 10 & Kesesuan & 1.680 & 1385 & $82 \%$ & Baik \\
\hline
\end{tabular}

Dari tabel diatas di didapatkan nilai pada indikator proses belajar memilik prosentase $83 \%$ dengan kategori baik, Motivasi $84 \%$ dengan kategori baik, Kepribadian $81 \%$ dengan kategori baik, Intensitas $86 \%$ dengan kategori baik, Size $87 \%$ dengan kategori baik, Keberlawanan $83 \%$ dengan kategori baik, Pengulangan 83\% dengan kategori baik, Gerakan 85\% dengan kategori baik, Hal Baru $82 \%$ dengan kategori baik, Keseluruhan $83 \%$ dengan kategori baik. Dari semua Indikator yang ada memiliki prosentase nilai rata-rata sebesar $83,7 \%$ dengan kategori baik. Dari hasil yang telah diuraikan paa tabel diatas hasil persepsi mengenai pembelajaran pendidikan jasmani olahraga dan kesehatan dapat ditarik kesimpulan baik. Hal tersebut yang dapat dijadikan sebagai patokan dalam pemberian pembelajaran kepada murid, dengan adanya pembelajaran daring seperti saat ini dengan adanya keterbatasan kegiatan belajar mengajar sehingga tenaga pendidik hanya bisa memberikan pemahaman mengenai teori secara detail dikarnakan tidak memungkinankan untuk dilakukan praktek secara langsung, mengingat pelajaran pendidikan jasmani olahraga dan kesehatan seharusnya teori disertai praktek seacra langsung.

Secara umum menurut Thoha (2011) jika persepsi murid dapat dikategorikan menjadi 2 faktor utama yaitu faktor internal dan faktor eksternal. Dimana Faktor Internal terdiri Proses kegiatan belajar, Motivasi belajar, dan kepribadian, Faktor eksternal terdiri dari Intensitas, Size, Berlawanan, Pengulangan, Gerakan dan hal-hal baru. Dari pendapat diatas dapat ditarik kesimpulan jika persepsi purid bisa dipengaruhi oleh faktor internal dan eksterna. Oleh sebab itu peran seorang sangat berpengaruh terhadap pembelajaran pendidikan jasmani dan kesehatan, dengan adanya ketrampilan skil 
yang dimiliki tenaga pengajar harus mampu memberikan kegaiatan pembelajaran secara menarik sehingga timbulkah persepsiyang baik dari murid.

\section{KESIMPULAN}

Berdasarkan pembahasan yang telah dijabarkan diatas dapat ditarik secara garis besar jika meskipun pembelajaran pada Murid SMK Negeri 10 Semarang dilakukan secara daring hanya teori saja yang bisa di berikan serta mengingat adanya keterbatasan mengenai proses belajar megajar, tetapi persepsi murid bisa dikategorikan baik. Sehingga untuk peneliti berikutnya supaya menggunakan pembelajatran yang mudah di pahami dan dimengerti oleh murid sehingga akan menimbulkan persepsi yang positif.

\section{DAFTAR PUSTAKA}

Agastya. (2015). Persepsi dan sikap Masyarakat Terhadap Penanggalan Jawa dalam Menentukan Waktu Pernikahan (Studi Kasus Desa Jonggrang Kecamatan Barat Kabupaten Magetan. Metrologika, 53.(5). 1-116

Firon, Mukhammad. (2020). Survei Tingkat Persepsi Siswa Terhadap Konsep Pendidikan Jasmani Di Sekolah Menengah Atas. Jurnal Sport Sienceand Helath. Vol 2.(5):2020.

Komarudin dan Mardianto Prabowo. (2020). Persepsi Siswa Terhadap Pembelajaran Daring Mata Pelajaran Pendidikan Jasmani Olahraga Dan Kesehatan Pada Masa Pandemi Covid 19 . Jurnal Ilmah Olahraga (Majora). Vol 26 (2)2020, 56-66.

Pahliwandari, R.(2016). Penerapan Pembelajaran Kognitif Dalam Pendidikan Jasmani dan Kesehatan. Jurnal Pendidikan Olahraga, 5.(2).154-164.

Rahayu, E.T (2013). Strategi Belajar Mengajar Penjaskes. Depdikbud : Jakarta

Rahman,Irfan. Ruslan Abdul Gani. (2020). Persepsi Siswa Dalam Pembelajaran Dan Pendidikan Jasmani Olahraga Dan Kesehatan Tingkat SMA. Jurnal Pendidikan Olahraga 9 (2) Desember 2020. Hal 144-154

Rodeiro. (2018). Proffesional Profile of graduates with a degree in physical activity and sports scient in Spain. Journal of Physical Education and Sports (JPES),18. (Suplement Issue) 3. Art 185. pp 1243-1247.

Sugiyono.(2018). Metode Penelitian Kualitatif, Kuantitatif dan R\&D. Alfabeta. Bandung.

Suhardi dan Nurcahyo. F. (2014). Persepsi Siswa SMK Negeri 2 Kabupaten Wonosobo Terhadap NilaiNilai Sosial dalam Kegiatan Ekstrakulikuler Permaian Sepakbola. Jurnal Pendidikan Jasmani dan Kesehatan 10 (2).20

Suprihati, Ningrum, J. (2014). Strategi Pembelajaran. Yogyakarta : AR-Ruzz Media.

Thoha, M. (2011). Perilaku Organisasi, Konsep Dasar dan Aplikasinya. Jakarta Rajawali Pers

Whitney, D.(2012). Perceiving Group Behaviour: Sensitive Ensemble Cooding Mechanism For Biological Motion of Human Crowds. 99-116. 